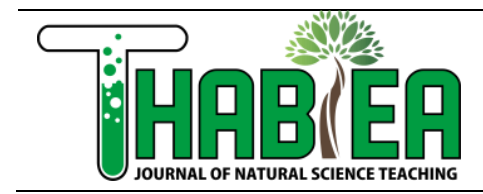

Thabiea : Journal of Natural Science Teaching

Vol.4(2), pp. 136-147, 2021

Available online at

http://journal.iainkudus.ac.id/index.php/Thabiea p-issn: 2580-8474, e-issn: 2655-898X

\title{
The Implementation of Islamic Values in Basic Physics Subject Based on Pre-Rules Method
}

\author{
Hanik Malichatin ${ }^{1 *}$, Faiq Makhdum Noor ${ }^{2}$ \\ State Islamic Institute of Kudus, Gondangmanis street No.51, Ngembalrejo, Kudus, \\ Central Java, 59322, Indonesia \\ *Correspondence: hanikm@iainkudus.ac.id
}

\begin{tabular}{ll}
\hline Keywords: & Abstract \\
Islamic values, & The purpose of this study is to describe the implementation of Islamic values in basic \\
Basic Physics & physics subject using the pre-rules method. The subjects of the study are Pre-Service \\
subject, & Biology Teachers (PBT) who attended basic physics lectures amount 51 students. Data \\
Pre-Rules Method & collection techniques are carried out by observation, questionnaire, and documentation. \\
& Data analysis is carried out by descriptive analysis. The process of implementing Islamic \\
& values is carried out in three stages, namely planning, implementation and evaluation. \\
& The planning stage is carried out by developing an integrated Lesson Plan by adding \\
& points of unity of sense. At the implementation stage, it is done by instilling divine \\
& values in prayer activities and linking the material with verses of the Al-Qur'an. In \\
& addition, human values such as discipline and responsibility are also applied. While the \\
& evaluation stage through the provision of integrated questions. The response of PBT to \\
this implementation shows that this integration is able to increase gratitude to God and \\
make basic physics subject more interesting.
\end{tabular}

To cite this article:

Malichatin, H., Noor, F.M., (2021). The Implementation of Islamic Values in Basic Physics Subject Based on Pre-Rules Method. Thabiea : Journal of Natural Science Teaching, 4(2), 136147.

\section{Introduction}

Learning is a process of changing behavior and knowledge. Learning can be carried out well if there is good interaction in each learning component, namely teachers, students, objectives, materials, media, methods, and evaluations (Pane \& Dasopang, 2017). One of the things that makes the learning process not run well is the learning material that is difficult to master. In basic physics material, there are some materials that are considered difficult. In Setiawan \& Rusdiana's research, it shows that fluid mechanics is a material that is more difficult than other materials. This is caused by several factors, including materials, students, lecturers, and the process of learning activities that have been carried out (Setiawan \& Rusdiana, 2020). In addition, based on Nugraheni's research, it is also difficult for pre-service teachers to solve mechanical problems. This is because pre-service teachers do not master the basic mathematics material, namely differential and integral (Nugraheni, 2017).

The difficulties faced by pre-service teachers can be overcome by presenting subject matter that is organized so that pre-service teachers can easily understand the material presented. In addition, the presentation of subject matter can also improve the ability to solve problems, communicate, and cooperate with pre-service teacher (Malichatin, 2013). The improvements in the learning process in basic physics subject can also be overcome by the use of a well-planned Lecture Program Unit (SAP) and the use of learning media in lectures. 
(Irianti, 2004). The efforts to introduce science through scientific literacy are also important to do from an early age so that science is easier to be understood by student. However, scientific literacy efforts have obstacles related to the understanding of pre-service teachers on how to teach and also assess the scientific literacy of students at an early age (Noor, 2020).

Science learning should not be separated from religious knowledge. The separation between science and religion has a negative impact on the future of humanity by only being introduced to science and religion knowledge separately (Bisyri, 2009). The impact of the dichotomy, especially in Indonesia, includes the stratification between two disciplines, namely general science education (science) and religious education (Islam) where religious education is considered inferior (Mustaqim, 2015). The dichotomy of education in Indonesia is caused by three things, namely, the dichotomy is a legacy of the colonial era, the dichotomy is still rooted in the post-colonial world of education, and the political problems of the power holders. (Kurniyat, 2018).

The efforts of Muslim scientists in overcoming the dichotomy problem are by integrating general knowledge (science) with religious knowledge (Islam) through the Islamization of Science. Islamization of science is to Islamize all scientific disciplines truly based on Islamic principles (faith/tawhid), and not to simply adopt western sciences that are secular, materialistic and rational, empirical (Wahyuni, 2018). Some of the advantages of education that applies non-dichotomous is that it will be able to realize: integration, interconnection, holistic, integrated, comprehensive, one system, one unified, solid, strong, collective, religious, humanist, peaceful, friendly, humble, thorough, hard work, work smart, quality work, thorough work, and sincere work. While the weakness when carrying out a dichotomous education is that it results in separation, independent, partial, incomplete, divided, fragmented, scattered, collapsed, weak, individual, secular, radical, anarchic, arrogant, incomplete, sluggish, give up quickly, carelessly, the results are not intact, selfishness and despair (Maksudin, 2015).

Integrated learning between religious and general science in the classroom requires the right learning syntax. Integrated learning syntax can be a guide for teachers in implementing integrated learning in the classroom. In addition, students gain an integrated and comprehensive learning experience from the point of view of science and Islam (Noor, 2012). In line with the concept of integration in non-dichotomous education, the MUI Fatwa has an important role as a basis/decision in solving people's problems. There are several Basic Competencies (KD) that can be associated with the MUI Fatwa such as additives, psychotropic-addictive substances, and environmental pollution (Imaduddin \& Khafidin, 2018). The MUI fatwa is the basis for integrating knowledge. In addition to the integration of Islamic scholarship in education, the practice of religious teachings can also be used in medicine, including Sufism therapy. Adlina, et al., in their research stated that Sufistic therapy is the treatment of the soul through certain practices in accordance with the teachings of Sufism. (Adlina et al., 2018). Sufistic therapy is carried out by performing ablution and bathing repentance for students who are seriously ill. As for students who are mildly ill, it is enough to attend congregational prayers and other cottage activities.

Islamic values are essentially a collection of life principles, teachings about how humans should live their lives in this world (Jempa, 2018). The integration of Islamic values into learning activities can be done through synchronous and asynchronous communication 
methods. The integration of Islamic values with synchronous communication methods is carried out by incorporating Islamic values into each teaching material in the form of images and videos that will be given to students in each learning activity. While the asynchronous communication method, the integration of Islamic values is carried out directly by the lecturer/tutor (Virgiawan, 2020). The results of Pertiwi's research show that meaningful learning can be achieved by integrating physics material with appropriate verses from the Qur'an. Thus, students appreciate and believe in the natural order of God's creation. This is in accordance with the purpose of science education in Indonesia, namely so that students have confidence in the orderliness of God's creation and the majesty of God Almighty (Pertiwi, 2016).

Learning in basic physics subject that apply Islamic values must be based on an agreement on lecture rules between lecturers and pre-service teachers. These rules are called the pre-rules method (Wiswanti \& Belaga, 2020). The use of the pre-rules method in learning can be applied through an agreement between lecturers and students contained in the semester learning plan and also the lecture contract. With this agreement both lecturers and students know the rules during the learning process that will be carried out for one semester so that can facilitate the process of learning. This is because in learning requires rules in the manufacture and process (Karlström \& Hamza, 2021). The rules before starting lectures are expected to make students more prepared in learning activities that apply Islamic values.

Based on the description, it is important to conduct research on the implementation of Islamic values in basic physics subject using the pre-rules method. The pre-service biology teachers are not only required to master physics and pedagogy, but also understand the relationship between every concept of physics and Islam knowledge.

\section{Method}

This type of research is a field research with a descriptive-qualitative type of research to collect information about symptoms in a situation (Arikunto, 2006). The factors studied were the process of implementing Islamic values in basic physics subject. The data sources in this study were pre-service biology teacher of IAIN Kudus who took basic physics subject in the 2020/2021 academic year amount 51 people. The sampling technique used was purposive sampling, that is, the researcher used all students who attended basic physics lectures without exception. Techniques data collection is done through observation, interviews and documentation. Observation techniques are used to observe the implementation of Islamic values in basic physics lectures covering the planning, implementation, and evaluation stages. Interviews were conducted to determine the pre-service biology teacher responses to the implementation of Islamic values in basic physics lectures. While the documentation technique is used to get a picture of the data from the subject's point of view through written media, for example examples of teaching materials and evaluation questions that integrate Islamic values. After collecting data using the instrument, the next step is data analysis. Data analysis techniques used include data reduction, data presentation, and conclusion drawing. The three stages of analysis are interactive. 


\section{Results and Discussion}

\section{1) Basic Physics Lectures that Integrate Islamic Values with the Pre-Rules Method}

As one of the Islamic educational institutions, IAIN Kudus has a vision to become one of the leading universities in the field of applied Islamic sciences (Unit TIPD STAIN Kudus, 2018). The consequence of this vision is that it encourages every lecture at IAIN Kudus to integrate Islamic values for both religious subjects and general subjects such as basic physics. This is also reinforced by the vision of the tarbiyah faculty, namely "Excellence in preparing and developing educators and education staff based on applied Islamic knowledge that are humanist, applicable and productive. (Unit TIPD STAIN Kudus, 2016).

Basic physics is one of the compulsory subjects given to tadris biology students at the Tarbiyah faculty of IAIN Kudus. This course aims to make students able to master the theoretical concepts of natural science, especially physics. Basic physics lectures for the even semester of the 2020/2021 academic year are designed by applying the Islamic integration method in every lecture material. The purpose of this integration is to create students as resources who have faith and piety values (IMTAQ) as well as science and technology (IPTEK). In addition, to direct students to have complete intelligence including intellectual intelligence, emotional intelligence and spiritual intelligence (Ikhwan, 2014). In addition, another goal of the process of integrating Islamic values in the learning process is so that the learning process carried out is not only a knowledge transfer process but also a process of transfer of etiquette (Zamhari \& Masamah, 2017).

The concept of integrating Islamic values in general scientific learning is based on the understanding that all knowledge, both general and religious, is a means to reach God. This confirms that life in this world demands the attainment of life in the hereafter. This is also in line with the terminology of Islamic philosophy which states that the Qur'an as God's revelation was revealed in two forms, namely the Qur'an in the form of written sheets that are read by humans and the Qur'an in sheet form such as the universe and the universe (Muspiroh, 2014).

In the Qur'an it is stated that science is an inseparable part of religion. This is also supported by the theory of integration in natural theology that by knowing the design of nature and being aware of the universe and its contents, the existence of God will be known (Waston, 2014). Because the truth of the Qur'an is absolute which comes directly from God, the Qur'an is used to test the truth of principles or principles in science. In learning science such as basic physics through the implementation of Islamic values, it will be able to bring pre-service teacher to have an awareness of the value of goodness and safety. With this value can create science that is humanities, namely science that brings goodness among others. In the end, learning that integrates Islamic values will form noble character.

Basically, the curriculum contained in the tadris biology department has provided many Islamic religious courses, the rest are education and study programs. One of the majors courses is basic physics. Based on this, it can be explained that the IAIN Kudus has provided pre-service teachers with good Islamic values and general values so that the graduates produced will become scientists who understand religious values (Kusuma, 2016).

So far, the process of basic physics lectures in biology classes has not integrated Islamic values so that it only focuses on physics material. For example, when discussing the origin of living things or the origin of the universe, it is only presented from the side of science, giving rise to a lot of polemics that eventually lead to misleading and dangerous opinions. In this opinion it is concluded that western science is infidel and must be abandoned (Purwanto, 2015). This shows that science is a product of human thought so that it will be possible to emerge more than one science. In his book, Purwanto (2015) explains that in the Qur'an there are 97 suras that explain science, both physics, biology and chemistry. This reason also underlies the integration of Islamic values in teaching materials that are implemented in basic physical lectures. 
The implementation technique carried out in this basic physics lecture is the pre-rules method, namely making several rules before the lecture process (Wiswanti \& Belaga, 2020). This rule is intended to expedite the lecture process that will be carried out while at the same time instilling discipline in pre-service teacher. The pre-rules method is made with the aim of explaining to pre-service teacher about the technical implementation of the lectures that will be carried out both related to material and pre-service teacher rules during lectures. Rules related to material, for example in basic physics lectures held in the even semester of the 2020/2021 academic year, are integrated with Islamic values. This means that in every discussion of the material at each meeting it is associated with Islamic values or verses of the Qur'an, both material made by lecturers and presentation material developed by pre-service teacher. The integration source can be taken from the interpretation of the Qur'an, the integrated science reference book of the Qur'an or from the website. Other regulations made regarding pre-service teacher discipline and the lecture process include: every pre-service teacher is required to dress neatly according to the Shari'a and must respect one another, start lectures by praying, turn on videos when the online lecture process is in progress. This rule is then stated in a mutually agreed lecture contract.

\section{2) Description of the Implementation Process of Islamic Values in Basic Physics Lectures}

The idea of integrating Islamic values with general knowledge is not a new thing. At present, integration has become an urgent need due to the emergence of many general sciences and religious or secular sciences, giving rise to the dichotomy of science. In this basic physics subject, the integration process of Islamic values in this basic physics course includes three stages, namely the planning stage, the implementation stage and the evaluation stage.

a. Planning stage

Planning is an activity carried out to determine the goals to be achieved in this basic physics course. The process begins with preparing materials and searching for literature related to Islamic values or verses of the Qur'an and interpreting or looking for a relationship between the explanation of the material and the verse. Not all materials are integrated with Islamic values or verses of the Qur'an. Only a few chapters of all the material that exists in one semester, for example material on measurement, expansion, temperature and heat, vibrations and waves, geometrical optics and fluids.

Furthermore, the mapping of the material is outlined in the semester learning plan and teaching materials. The implementation process in the semester program plan (RPS) developed for basic physics courses is contained in the "unity of sciences" point. In this section exemplified the verses of the Qur'an that are integrated with physics material. For example, in geometry optics, it is associated with QS. Al Baqarah verse 17 which means:

"Their likeness is as the likeness of one who kindleth fire, and when it sheddeth its light around him Allah taketh away their light and leave them in darkness, where they cannot see".

In addition, the measurement material is integrated with QS Al-Qamar: 46 as shown in Figure 1. 


\begin{tabular}{|c|c|c|c|c|c|c|c|}
\hline $\begin{array}{l}\text { We } \\
\text { eks }\end{array}$ & $\begin{array}{l}\text { Sub-CP-MK } \\
\text { (as the } \\
\text { expected final } \\
\text { ability) }\end{array}$ & Indicator & $\begin{array}{c}\text { Criteria \& } \\
\text { Assessment } \\
\text { Form }\end{array}$ & $\begin{array}{c}\text { Learning } \\
\text { methods } \\
\text { (Estimated } \\
\text { time) }\end{array}$ & $\begin{array}{l}\text { Learning } \\
\text { Materials } \\
\text { [Library] }\end{array}$ & $\begin{array}{c}\text { Content Unity } \\
\text { of Sicences }\end{array}$ & $\begin{array}{c}\text { Rating } \\
\text { Percent } \\
\text { age } \\
(\%) \\
\end{array}$ \\
\hline (1) & $(2)$ & (3) & (4) & (5) & (6) & & (7) \\
\hline 1 & $\begin{array}{l}\text { Students are } \\
\text { able to apply } \\
\text { the concepts } \\
\text { of } \\
\text { measurement, } \\
\text { vector, and } \\
\text { quantities and } \\
\text { units in } \\
\text { everyday life. }\end{array}$ & $\begin{array}{l}\text { - Students are } \\
\text { able to } \\
\text { measure } \\
\text { various } \\
\text { quantities in } \\
\text { everyday life } \\
\text { with precise } \\
\text { and } \\
\text { meticulous. } \\
\text { - Students are } \\
\text { able to apply } \\
\text { vector } \\
\text { analysis in } \\
\text { solving daily } \\
\text { life problems } \\
\text { appropriately. } \\
\text { - Students are } \\
\text { able to use } \\
\text { quantities and } \\
\text { units in daily } \\
\text { life } \\
\text { appropriately }\end{array}$ & $\begin{array}{l}\text { Creteria: } \\
\text { Accuracy } \\
\text { and Mastery } \\
\text { Non-test } \\
\text { Form: } \\
\text { - Paper } \\
\text { writing } \\
\text { - Presentati } \\
\text { on }\end{array}$ & $\begin{array}{l}\text { - Lecture \& } \\
\text { Discussion } \\
\text { [TM: } \\
2 \text { x(2x50”) } \\
\text { ] } \\
\text { - Task-1: } \\
\text { Compile a } \\
\text { summary } \\
\text { of the } \\
\text { concepts } \\
\text { of } \\
\text { measurem } \\
\text { ent, } \\
\text { vector, and } \\
\text { quantities } \\
\text { and units } \\
\text { in } \\
\text { everyday } \\
\text { life. } \\
\text { [BT+BM:(1 } \\
+1) \times(2 \times 60 ") \\
\text { ] }\end{array}$ & $\begin{array}{l}\text { - Measure } \\
\text { ment } \\
\text { - Vector } \\
\text { - Quantity } \\
\text { and Unit }\end{array}$ & $\begin{array}{l}\text { Physical } \\
\text { Quantity } \\
\text { "We have } \\
\text { created } \\
\text { everything by } \\
\text { measure". (Al } \\
\text { Qamar: } \\
\text { 49) } \\
\text { "He unto } \\
\text { Whom belong } \\
\text { the Sovereignty } \\
\text { of the heavens } \\
\text { and the earth, } \\
\text { He hath chosen } \\
\text { no son nor hath } \\
\text { He any partner } \\
\text { in the } \\
\text { Sovereignty. He } \\
\text { hath created } \\
\text { everything and } \\
\text { hath meted out } \\
\text { for it a } \\
\text { measure." (Al } \\
\text { Furqan :2) } \\
\text { The two verses } \\
\text { above suggest } \\
\text { that the word } \\
\text { "Measurement" } \\
\text { is what exists in } \\
\text { nature can be } \\
\text { expressed in } \\
\text { two roles, the } \\
\text { first as a } \\
\text { number with } \\
\text { the nature and } \\
\text { accuracy } \\
\text { contained } \\
\text { therein and the } \\
\text { second as a law } \\
\text { or rule. } \\
\text { rule }\end{array}$ & 10 \\
\hline
\end{tabular}

Figure 1. Semester Lesson Plan (RPS) that integrates Islamic values

The Semester Lesson Plan (RPS) that has been developed is used as a reference in making teaching materials and evaluation questions used in lectures. In addition, the integration process is also developed in the lecture process by applying divine and human values to strengthen the attitudes of prospective teacher students.

b. Implementation stage

Basic physics lectures in the even semester of the 2020/2021 academic year are conducted online using various platforms. Every meeting always begins with greetings and prayer activities. This prayer activity is intended to strengthen the divine values or 
the faith values of prospective teacher students. It is also intended to equip pre-service teachers that in teaching science for the students, they are not only conveying general knowledge, but also religious values, especially for physics subjects. In the Qur'an it is explained that events in the universe are lessons for people to think (Tebriani, 2020). In studying general science must be accompanied by understanding that everything is God's creation. Therefore, it is necessary to understand the ins and outs of both the physical properties, the constituent components, and the processes that occur in it. Efforts to understand this can be done both psychologically and sociologically. In general, it can be explained that something that is learned in general science is an order from the Qur'an. Therefore, as the beginning of integration activities and strengthening the faith values of prospective teacher students, it is carried out with prayer activities.

After the prayer activity, the lecturer ensures that each student obeys every rule that has been made previously. Lecturers ensure that each student is neatly dressed and according to the Shari'a. This activity is carried out after all students turn on the video. Some of these activities aim to strengthen the value of Islamic character possessed by prospective teacher students. The process of implementing Islamic values is then carried out on the material. However, this integration is still limited to linking teaching materials with relevant Qur'anic verses and linking materials to concepts taught by Islam. The selection of the verses of the Qur'an in accordance with the material is carried out through a literature study, both from reference books, journal articles and websites of Al-Qur'an interpretation. The results of the selection of the paragraph are then developed in the presentation of the material (hand out) used in the lecture process, whether developed by lecturers or students as presentation material. In this study, the material that is integrated with Islamic values is the teaching material in the basic physics lesson plan. The minimum standard applied in integrating values is to relate them to the verses of the Qur'an. The example of material that integrates Islamic values in the form of integration of Al-Qur'an verses is shown in Figure 2. 
Mathematically the value of the speed of light can be calculated using the electric constant $\left(\varepsilon_{0}\right)$ to determine $c$ from the formula:

$$
c=\frac{1}{\sqrt{\varepsilon_{0} \mu_{0}}}
$$

In Islam, the calculation of light is carried out by a Muslim physicist from Egypt named Dr. Mansour Hassab El-Naby was also very influential in these calculations. Dr. Mansour Hassab El-Naby invented a special way to measure the speed of light. According to Dr. El Naby, the value of c can be determined precisely based on information from very old documents. This calculation is using information from the scriptures that were revealed 14 centuries ago. In the Qur'an it is stated in QS Yunus verse 5 which reads:

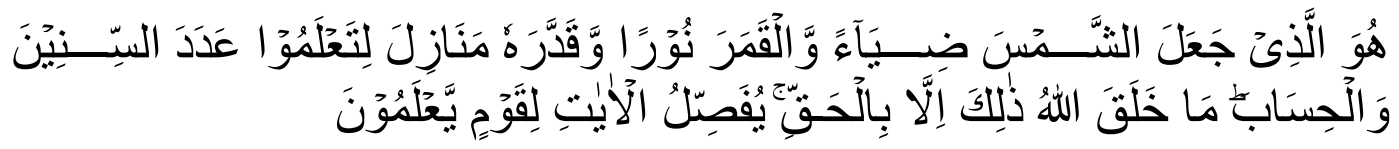

Meaning:

"He it is Who appointed the sun a splendour and the moon a light, and measured for her stages, that ye might know the number of the years, and the reckoning. Allah created not (all) that save in truth. He details the revelations for people who have knowledge."

Figure 2. Light teaching materials that integrate Islamic values

Based on the results of questionnaire with pre-service teachers regarding the integration of basic physics courses with Islamic values, this process provides more value for pre-service teachers. This is able to add insight to pre-service teachers that studying physics can also increase faith. As many as $76.5 \%$ of students who attended lectures stated that this basic physics course could make them aware that physics also comes from Allah because it is widely discussed in the Qur'an. This can be seen from the integration of Islamic values into the material at each meeting. Every material discussed in physics is contained in the Qur'an and there are moral values that can be taken so that it can also increase gratitude. Based on the results of the questionnaire, it is also known that the existence of the pre-rules method and the integration of Islamic values makes basic physics lectures different and more interesting..

The second process of implementing Islamic values carried out in basic physics lectures is by linking the material with the concepts taught by Islam. The purpose of studying physics should not only be to learn the concepts of physics but also to get to know more about Islamic concepts through the concepts studied in physics. The harmony between general and Islamic science shows that science is beneficial for Muslims. This is a form of response to the social crisis caused by the western education paradigm from the point of view of worldly science (Alwi, M., 2017). Islamic values applied in basic physics lectures are human values. Human values are defined as values that are born from the culture of society, both individually and socially. The social values developed in this course include: social values, responsibility, and discipline. 
Social values are applied when the discussion process takes place where every pre-service teacher is emphasized to always be friendly and respect the other opinions. The second value is responsibility. This value is applied by always emphasizing on pre-service teacher to complete each task given on time. While the value of discipline is applied in every lecture process, for example, pre-service teacher are required to be present at every lecture and are given a tolerance of 10 minutes after lecture hours begin. If after ten minutes, the pre-service teacher is allowed to attend the lecture but is not absent. This is applied during the lecture process and is agreed upon by all prospective teacher students. As a result, for sixteen face-to-face meetings, $94 \%$ of preservice teacher attended lectures with discipline. Another thing related to the discipline applied to this basic physics course is the discipline of time. Usually each assignment given to pre-service teacher is given a time limit for collection. The application of this disciplinary attitude is not immediately formed. In the first few meetings, the lecturer always reminded them of the lecture time rules and tolerances and reminded them of the deadline for submitting assignments. After the fifth meeting, the pre-service teacher were getting used to the rules so that no one was late for collecting assignments.

The strategy for applying human values used in this basic physics course is a traditional strategy or indoctrination with an action approach (Mubasyararoh, 2013). The indoctrination strategy is carried out by providing an understanding between good and bad values. While the action approach was chosen because during the lecture process, pre-service teacher were directly involved in the application of these values

c. Evaluation stage

Evaluation activities are an important part of the learning process. Evaluation is used to measure the achievement of learning objectives. Evaluation can be done in writing or orally. In the basic physics course, evaluation activities are carried out through assignments, quizzes, mid-semester exams and end-semester exams. Written evaluation is done by giving questions that are integrated with Islamic values or verses of the Qur'an. One example of the evaluation questions used is shown in Figure 3.

Ibn Haitham is one of the great figures of Islam in the field of optics. One of his manuscripts is Kitab Al Manazir. Ibn Haitham, he argues that the red light on the horizon in the morning (dawn) begins when the sun is 19 degrees below the horizon. Meanwhile, the red light on the skyline at dusk (mega) will disappear when the sun is 19 degrees below the horizon after the sun falls. In the concept of physics, what law is this statement called? Explain the law!

Al-Qur'an Yunus:5 Allah says: "He it is Who appointed the sun a splendour and the moon a light, and measured for her stages, that ye might know the number of the years, and the reckoning. Allah created not (all) that save in truth. He details the revelations for people who have knowledge".

Al-Qur'an Al-Anbiya:33 Allah says: "And $\mathrm{He}$ it is Who created the night and the day, and the sun and the moon. They float, each in an orbit."

Calculate the speed of light by analysing the verse!

Figure 3. Evaluation questions that integrate the verses of the Qur'an and Islamic values 
Based on the results of the evaluation by integrating Islamic values, it was found that the form of questions that were integrated with Islamic values did not reduce pre-service teacher' understanding of the matter. In addition to the evaluation in the form of a test, at the end of the sixteenth meeting, a questionnaire was also given to determine the response of preservice teacher to the application of basic physics lectures integrated with Islamic values. Most of the pre-service teacher stated that the application of Islamic values in basic physics lectures made this course different from other general courses. Another thing that was found was that by linking physics material with Islamic values, it was able to increase gratitude towards Allah SWT and realize that general knowledge such as physics also comes from Allah. It has even been explained that the Qur'an invites to think with various editors (for example, tafakkur, tadzakkur, tadabbur) about everything. Although basic physics lectures have implemented Islamic values, there are still some shortcomings, including the process of integrating teaching materials with the verses of the Qur'an should be consulted first with experts in the Qur'an or hadith so that there are no errors. In this study, only a few materials were consulted with material experts while others took interpretations from online sources or from existing references. This is also caused by internal factors, namely the low understanding of lecturers about the verses of the Qur'an. It is better if there needs to be more mature preparation to apply the pre-rules method and integrate it with Islamic values. In addition, it is necessary to have material mapping that allows it to be integrated with Islamic values, and consult the results of the integration with experts so that it does not cause conceptual errors.

\section{Conclusion}

The implementation of Islamic values in basic physics courses is carried out using the pre-rules method, namely making rules at the beginning of the lecture to link Islamic material in each lecture material. The implementation process is carried out through the planning, implementation and evaluation stages. The planning stage is carried out by developing lesson Plan in which there are Islamic values in the Unity of Science section. At the implementation stage, it is done by integrating the verses of the Qur'an in each material (divine values) and teaching Islamic attitudes/characters such as honesty, discipline and responsibility (human values). The last stage is evaluation to measure the achievement of the learning objectives that have been set. At this stage, it is done by giving assignments/practice questions and quizzes that are integrated with Islamic values. From the results of the implementation of integrating Islamic values in the lecture process, it turns out that it can increase pre-service teacher' gratitude for the greatness of God and also make basic physics lectures more interesting and different from other general subjects.

\section{References}

Adlina, A. U., Malichatin, H., \& Muarifah, F. (2018). Manfaat Terapi Sufistik bagi Santri Super di Pondok Pesantren at-Taqy Jepara. Esoterik, 4(1), 188. https://doi.org/10.21043/esoterik.v4i1.5759

Alwi, M. (2017). Islamisasi Ilmu Pengetahuan Kontribusi Dalam Mengatasi Krisis Masyarakat Modern. Lentera Pendidikan, 6(2).

Arikunto, S. (1998). Prosuder Penelitian Suatu Pendekatan Praktek. PT. Rineka Cipta.

Bisyri, M. H. (2009). Mengakhiri Dikotomi Ilmu Dalam Dunia Pendidikan. Forum Tarbiyah, $7(2), 14$

Ikhwan, A. (2014). Integrasi Pendidikan Islam (Nilai-Nilai Islami dalam Pembelajaran). Ta'allum Jurnal Pendidikan Islam, 2(2), 174-194.

Imaduddin, M., \& Khafidin, Z. (2018). Ayo Belajar IPA dari Ulama: Pembelajaran Berbasis Socio-Scientific Issues di Abad ke-21. THABIEA : JOURNAL OF NATURAL SCIENCE TEACHING, 1(2), 102. https://doi.org/10.21043/thabiea.v1i2.4439 
Irianti, M. (2004). Perbaikan Proses Pembelajaran Mata Kuliah Fisika Dasar I Pada Mahasiswa Program Studi Pendidikan Biologi Fkip Universitas Riau. 6(1), 10.

Jempa, N. (2018). Nilai-Nilai Agama Islam. 1(2), 12.

Karlström, M., \& Hamza, K. (2021). How Do We Teach Planning to Pre-service Teachers - A Tentative Model. Journal of Science Teacher Education, 1-22. https://doi.org/10.1080/1046560X.2021.1875163

Kurniyat, E. (2018). Memahami Dikotomi dan Dualisme Pendidikan di Indonesia. Rausyan Fikr : Jurnal Pemikiran dan Pencerahan, 14(1). https://doi.org/10.31000/rf.v14i1.669

Kusuma, H. H. (2016). Korelasi Hasil Belajar Fisika Dasar dan Tafsir Terhadap Kemamapuan Integrasi Bagi Mahasiswa Jurusan Pendidikan Fisika UIN Walisongo Semester VII Tahun 2014/2015. Phenomenon: Jurnal Pendidikan MIPA, 5(1), 45-54. https://doi.org/DOI:10.21580/phen.2015.5.1.90

Maksudin, M. (2015). Transformasi Pendidikan Agama dan Sains Dikotomik ke Pendidikan $\begin{array}{lllll}\text { Nondikotomik. Jurnal Pendidikan } & 277 .\end{array}$ https://doi.org/10.14421/jpi.2015.42.277-298

Malichatin, H. (2013). Pengembangan materi subjek bagi mahasiswa calon guru fisika. Journal of Innovative Science Education, 2(1).

Mubasyararoh. (2013). Pendidikan Penanaman Sistem Nilai Dalam Pembelajaran Aqidah Akhlaq. 8(2), 291-310.

Muspiroh, N. (2014). Integrasi Nilai-Nilai Islam dalam Pembelajaran IPA di sekolah. Equity, 2(1), 168-188. http://dx.doi.org/10.21043/quality.v2i1.2099

Mustaqim, M. (2015). Pengilmuan Islam dan Problem Dikotomi Pendidikan. JURNAL PENELITIAN, 9(2), 255. https://doi.org/10.21043/jupe.v9i2.1321

Noor, F. M. (2012). Integrasi-Interkoneksi Keilmuan Sains dan Islam dalam Proses Pembelajaran Fisika. Prosiding: Seminar Nasional Fisika dan Pendidikan Fisika, 3(4), 10.

Noor, F. M. (2020). Memperkenalkan Literasi Sains Kepada Peserta Didik: Perspektif Calon Guru PIAUD. ThufuLA: Jurnal Inovasi Pendidikan Guru Raudhatul Athfal, 8(1), 056067. https://doi.org/10.21043/thufula.v8i1.7066

Nugraheni, D. (2017). Analisis Kesulitan Belajar Mahasiswa pada Mata Kuliah Mekanika. Edu Sains: Jurnal Pendidikan Sains \& Matematika, 5(1), 23. https://doi.org/10.23971/eds.v5i1.586

Pane, A., \& Dasopang, M. D. (2017). Belajar dan Pembelajaran. 03(2), 20.

Pertiwi, F. N. (2016). Pembelajaran Fisika Dasar Terintegrasi Nilai-Nilai Pendidikan Islam Melalui Diagram Vee. Ibriez : Jurnal Kependidikan Dasar Islam Berbasis Sains, 1(1), 35-46. https://doi.org/10.21154/ibriez.v1i1.7

Purwanto, A. (2015). Ayat-ayat Semesta: Sisi-sisi Al-Qur'an yang Terlupakan. Mizan Pustaka.

Setiawan, A., \& Rusdiana, D. (2020). Penelusuran Peringkat Kesulitan Materi dalam Fisika Dasar. 8(1), 4.

Tebriani, S. (2020). Filosofi dalam Islamisasi Pembelajaran Fisika. Natural Science: Jurnal Penelitian Bidang IPA dan Pendidikan IPA, 6(2), 7.

Unit TIPD STAIN Kudus. (2016). Fakultas Tarbiyah IAIN Kudus. -. https://tarbiyah.iainkudus.ac.id/index.php?page=halaman\&id=135

Unit TIPD STAIN Kudus. (2018). Profil-Iainkudus.ac.id. https://iainkudus.ac.id/temp/u01/profil.php

Virgiawan, R. (2020). Penerapan Nilai-Nilai Islam Dalam Sistem Pembelajaran Daring. Refleksi Pembelajaran Inovatif, $2(1), \quad$ Article 1. https://doi.org/10.20885/rpi.vol2.iss1.art2

Wahyuni, F. (2018). Islamisasi Ilmu Pengetahuan (Upaya Mengurai Dikotomi Ilmu Pengetahuan dalam Islam). 10(2), 12. 
Waston. (2014). Hubungan Sains dan Agama: Refleksi Filosofis atas Pemikiran Ian G. Barbour. Profetika: Jurnal Studi Islam, 15(1), 76-89. https://doi.org/10.23917/profetika.v15i1.1968

Wiswanti, C., \& Belaga, S. Y. (2020). Integrasi Nilai Keislaman Dalam Proses Pembelajaran Di Era Mooc (E-Learning) Melalui Strategi Pre-Post Rules. Jurnal Pendidikan Islam, 11(1), 86-99. https://doi.org/10.22236/jpi.v11i1.5037

Zamhari, M., \& Masamah, U. (2017). Relevansi Metode Pembentukan Pendidikan Karakter Dalam Kitab Ta'lim Al-Muta'allim Terhadap Dunia Pendidikan Modern. Edukasia: Jurnal Penelitian Pendidikan https://doi.org/10.21043/edukasia.v11i2.1724

Islam, $\quad 11(2)$, 421. 